Management of a Patient with Esophageal Stricture after Drinking Strongly Acidic Water by Dedi Hadi Prawono

Submission date: 27-Aug-2019 09:57AM (UTC+0800)

Submission ID: 1163831608

File name: IMRM_2017_83.pdf (374.66K)

Word count: 3968

Character count: 23038 


\section{Management of a Patient with Esophageal Stricture after Drinking Strongly Acidic Water}

Dedy Hadi Prawono, Budi Widodo, Iswan Abbas Nusi, Poernomo Boedi Setiawan, Herry Purbayu, Titong Sugihartono, Ummi Maimunah, Ulfa Kholili, Amie Vidyani, Muhammad Miftahussurur and Husin Thamrin

Department of Internal Medicine, Dr. Soetomo Teaching Hospital, Faculty of Medicine, Universitas Airlangga, Jl. Prof dr. Moestopo 47, Surabaya 60132, Indonesia

apji@fk.unair:ac.id

Keywords: Corrosive, Esophageal Stricture, Esophagus, Mucosa, Strongly Acidic.

Abstract: This report concerns a case of esophageal stricture treatment after drinking corrosive substances (strong acid). Esophageal stricture can be caused by a malignancy and non-malignancy, including strong acid. Manifestations of esophageal stricture include swallowing difficulty, particularly solid food, sore throat on swallowing, and history of drinking or ingestion of corrosive substances. The therapeutic principle of esophageal stricture includes maintaining the esophageal mucosa to maintain good esophageal patency, esophageal diameter, minimizing stricture and fibrosis formations, and minimizing mucosal tissue damage.

\section{INTRODUCTION}

Esophageal stricture is esophageal luminal narrowing due to esophageal wall fibrosis. Stricture occurs due to inflammatory processes and esophageal necrosis (Simadibrata, 2009). The cause of esophageal stricture is divided into malignant and benign tumors. Malignant tumor occurs in all parts of the esophagus, most commonly in the middle $(50 \%)$, distal $(35 \%)$ and proximal $(15 \%)$ of the esophagus, with frequent causes of squamosal cell carcinoma and adenocarcinoma. Benign consists of corrosive/caustic substances, esophageal reflux disease, postoperative esophageal transfusion and endoscopic endosclerotherapy. The most common benign cause of benign esophageal stricture is peptic esophageal stricture (70-80\%) (Khanna, 2006).

Corrosive substances can be acidic and alkaline. Mucosal damage caused by corrosive substances may appear 1-2 months post-contact. Esophageal damage caused by corrosive substances may occur in the proximal esophagus and middle esophagus. Corrosive alkaline substances are commonly found in European countries, while the acidic substances are found in developing countries such as India and Indonesia since hydrochloric and sulfuric acid are very easy to obtain. Mucosal damage caused by both acid and alkaline is very different. Acid-induced damage can cause necrosis, as evidenced by scars of the affected mucosa. This mucosa damage can occur with minimal contact dose. Meanwhile, alkalineinduced mucosal damage will cause liquefactive necrosis and saponification. The damage can reach the deep mucosal layer. The alkaline-induced damage requires large doses and prolonged contact to cause mucosal damage (Sandro, 2013; Osman, 2008; Ilkin, 2006; Sajida, 2010).

Regardless of the above classification, stricture caused by special strongly acidic corrosive substances has extensive clinical manifestations, including esophageal stenosis dysphagia, burning sensation in the chest or chest discomfort (this will not occur if mucosal damage is not more than $70 \%$ ), stridor breathing sounds, hoarseness and salivate (Sandro, 2013).

\section{CASE}

The following is a case report of an esophageal stricture patient and anatomic gastric changes after drinking car battery water: a man, $\mathrm{Mr}$. $\mathrm{M}$, aged 48 years old, Javanese, pump machine mechanic in Lapindo, living in Sidoarjo, visited Dr. Soetomo 
General Hospital, Surabaya, Indonesia, due to body limpness and swallowing difficulty after drinking car battery water 6 months before.

Primary complaint: weakness and body limpness in the last 2 months, which increased until the patient could not walk. The patient was weak since he could not eat and drink. He initially found it difficult to swallow solid food until there was difficulty in drinking or swallowing saliva. He had weight loss for 2 months. The complaints occurred after the patient accidentally drank car battery water 6 months before while working as a pump operator in Lapindo. The patient had not eaten before drinking the car battery water, and he had a burning throat complaint after drinking the water. $\mathrm{He}$ was immediately admitted to Bhayangkara Hospital, Porong, Indonesia, and he was treated for 4 days. On day 2 post discharge, the patient had vomiting. Therefore, he was admitted to Sidoarjo General Hospital, Sidoarjo, Indonesia. The patient was diagnosed with esophageal stricture. On day 2 postendoscopy, he was referred to Dr. Soetomo General Hospital, Surabaya, Indonesia. The patient was observed for 3 months with medicine administration. One month later, he visited the Gastroenterology Unit of Dr. Soetomo General Hospital, Surabaya Indonesia, for control since he had swallowing difficulty and body weakening complaints. One month later, the patient underwent endoscopy examination, with the results showing a narrowing in the upper esophagus. The patient was given orally-administered drugs (the patient forgot the drugs' names) for 1 month. One month later, he visited the Gastroenterology Unit for control since he felt no improvement.

Physical examination showed a general weakness with GCS 456, blood pressure 110/80 $\mathrm{mmHg}$, pulse 104 times $/ \mathrm{min}$, regular rhythm, strength lift, normal amplitude, respiratory rate 18 times $/$ min, axillary temperature $36.7^{\circ} \mathrm{C}$, VAS 1 and SGA 6. Head neck examination: normal conjunctival, no scleral icterus, no cyanosis nor dyspnea, no increase in jugular venous pressure nor swollen lymph nodes.

Thoracic examination: visible malnutrition, symmetrical movement, no intercostal nor supraclavicular retraction. The heart examination found single S1 and S2 heart sounds, regular, no heart sound, gallop rhythm or pericardial friction. The lung examination found vesicular breathing sounds in both hemithorax, but neither rhonchi nor wheezing was found in either lung field. Abdominal examination: normal bowel sounds, firm palpability. Liver and lien were not palpable. Extremity examination: reddish, warm, dry extremities, no extremity edema. Neurological examination: motor and sensory systems within normal limits, no lateralization, normal physiological reflexes, no pathological reflex.

The patient's endoscopy data (April 19, 2017) from Sidoarjo General Hospital, Surabaya, Indonesia, showed esophagitis with an open wound, stricture/ esophageal narrowing $1 / 3$ distal. The esophagogram (July 8,2017 ) found a plain X-ray without corpus alienum/mass, barium contrast material, central esophagus proximal. Contrast material entered distally, swallowing difficulty, coughing and choking, aspiration and contrast material entered the airway, and the examination was stopped

Laboratory test showed a hemoglobin level of $11.6 \mathrm{~g} / \mathrm{dL}$, leukocytes 10,600 cells $/ \mathrm{mm}^{3}$, neutrophils $78.4 \%$, albumin $3.57 \mathrm{~g} / \mathrm{dL}$, random blood glucose level $80 \mathrm{~g} / \mathrm{dL}$, hepatic and renal function within normal limits. Non-reactive HbSAg, Na 130, K 4.5, $\mathrm{Cl}$ 90. Thoracic radiographic examination showed no abnormality. An endoscopy examination performed at Dr. Soetomo General Hospital, Surabaya, Indonesia, (July 4, 2017) found a small lumen and stricture, with stricture esophagus diagnosis.

Based on anamnesis, physical and supportive evaluations, the patient was diagnosed with stricture esophagus $1 / 3$ distal caused by car battery water and esophagitis. Planned diagnosis: esophagography and endoscopy. Initial therapy: total parenteral nutrition, $2 \times 40 \mathrm{mg}$ omeprazole injection, $3 \times 1$ metoclopramide, sucralfate $3 \mathrm{dd}$ CII drug active and passive physiotherapy.

Day-7 treatment: the patient underwent gastroscopy and CRE balloon dilatation with a diameter of $12 \mathrm{~mm}$, pressure 3 ATM, for 2 minutes. The therapy continued with a submucosal injection of triamcinolone at a dose of $0.4 \mathrm{mg}$. Examination of the proximal and distal esophagus found a proximal esophageal stricture. The patient received partial parenteral nutrition and a milk diet of 4 tablespoons every 2 hours, and intravenous injection of methylprednisolone $1 \times 62.5 \mathrm{mg}$ after endoscopy. The patient was also given an explanation regarding his illness condition. In day-14 treatment, the patient had an endoscopic examination with a scope inserted into the distal esophagus up to $40 \mathrm{~cm}$. The examination found a visible lumen narrowing, with the esophagus wall covered with scar tissue. Wire was installed using c-arm assistance. A CRE balloon dilatator was inserted and the lumen was sequentially dilated to $15 \mathrm{~mm}$ with a pressure of 3 
$\mathrm{mm}$. The scope was advanced to the distal esophagus up to $50 \mathrm{~cm}$ from the mouth piece, the lid was shrunk with scar tissue around it, the lumen was narrowed to $55 \mathrm{~cm}$ from the mouth piece, lumen did not expand, a CRE balloon was installed and the lumen was sequentially dilated up to an $18 \mathrm{~mm}$ diameter at 5 ATM pressure, and the lumen widened. A submucosal injection of triamcinolone at a dose of $0.4 \mathrm{mg}$ was given in the dilated area and scar, the patient received methylprednisolone $3 \times 14$ $\mathrm{mg}$ orally, and an enteral $20 \mathrm{cc}$ of enteral diet each hour which was gradually raised, with partial parenteral nutrition. The patient began to drink after the second endoscopy, with reduced vomiting and spitting complaints. On day 20 , the patient went home and he could drink $20 \mathrm{cc}$ of milk every hour and eat cereal.

\section{DISCUSSION}

The esophagus is a muscular tube connecting and transporting food from the mouth to the stomach. The esophagus has several compartments: $5-\mathrm{cm}$ pars cervicalis between the trachea and columna cervicalis, the chest (pars thoracalis) as high as the sternum manubrium in the posterior mediastinum, the abdominal (abdominal pars) enters into the abdominal cavity through the esophageal hiatus from diaphragm which ends at the cardiac stomach, as shown in Figure 1. The esophagus has 3 constricted areas: caused by the cricopharyngeal muscle, crossbreeding with the left bronchus and aortic arch, and gastroesophageal sphincter mechanism. The esophageal wall consists of 4 layers: the mucosal layer, submucosa, the muscle layer and the fibrous layer. The mucosal layer comprises a non-keratinized flat-topped epithelium. The submucosal layer consists of thick collagen fibers, elastin fibers, mucous glands and Meissner's plexus. The muscle layer is comprised of smooth muscle and striated muscle, and the mesenteric plexus is located between the two muscle layers. In addition to food channel, the esophagus also has a function as a place of swallowing process. There are three phases of swallowing process: buccal, pharyngeal and esophageal phases (Harjadi, 2009).

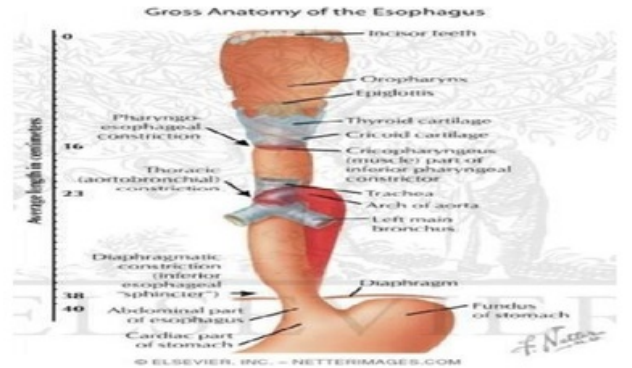

Figure 1: Gross Anatomy of the Esophagus (Harjadi, 2009).

The stomach is the most widened digestive organ located between the esophagus and the small intestine. Anatomically, the stomach has five parts: cardiac, fundus, body, antrum and pylori (Figure 2). The stomach wall consists of 4 layers, including mucosa, submucosa, muscularis externa and serosa (Harjadi, 2009).

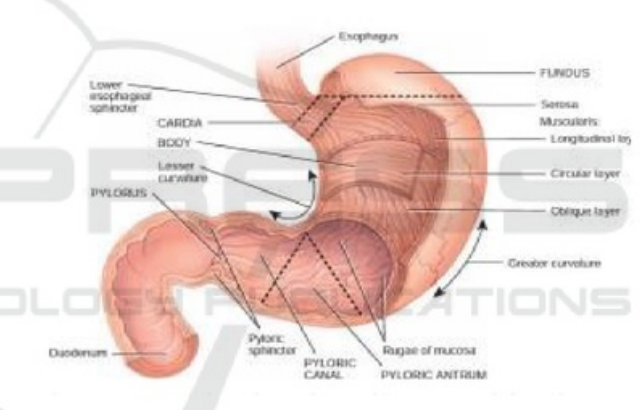

Figure 2: Stomach Anatomy (Harjadi, 2009).

Epidemiological data on esophageal stricture prevalence vary depending on the geographic region. In the U.S., there are 25,000 acid-induced esophageal stricture cases per year. Most of them commonly occur in children with 17,000 cases per year, while the rest occur in young adults, resulting from suicide attempts (Kay, 2009; Hawkey, 2013). A study found that esophageal stricture was caused by corrosive substances $(16,59.3 \%)$ and gastric acid $(10,37 \%)$. The sex ratio of corrosive substanceinduced esophageal stricture was $1: 2.2$, while $1: 2.3$ for gastric acid. The length of stricture due to corrosive substance and gastric acid were $8.88 \mathrm{~cm}$ and $3.9 \mathrm{~cm}$, respectively (Sajida, 2010). 
Table 1: Esophageal Stricture due to Corrosive Substances and Gastric Acid (Sajida, 2010).

\begin{tabular}{|c|c|c|c|}
\hline & Corrosive & Peptic & $\mathrm{p}$ \\
\hline Patients (n) & $16(59.3 \%)$ & $10(37 \%)$ & \\
\hline $\begin{array}{ll}\text { Sex ratio } \\
(\mathrm{M}: \mathrm{F})\end{array}$ & $5: 11$ & $3: 7$ & $<0.802$ \\
\hline Age (mean) & $\begin{array}{l}25.88( \pm 13 . \\
720)\end{array}$ & $\begin{array}{l}42.80( \pm 19.159 \\
)\end{array}$ & $<0.015$ \\
\hline Intent & $\begin{array}{l}\text { Suicidal } \\
11 / 16(68.7 \\
5 \%)\end{array}$ & $\mathrm{N} / \mathrm{A}$ & $<0.001$ \\
\hline $\begin{array}{l}\text { Mean } \\
\text { Length of } \\
\text { stricture } \\
(\mathrm{cm})\end{array}$ & $\begin{array}{l}8.88 \\
( \pm 5.999)\end{array}$ & $3.90( \pm 1.729)$ & $<0.006$ \\
\hline $\begin{array}{l}\text { Mean } \\
\text { location of } \\
\text { stricture } \\
\text { from } \\
\text { incisors } \\
(\mathrm{cm})\end{array}$ & $\begin{array}{l}22.44( \pm 5.2 \\
40)\end{array}$ & $30.20( \pm 4.780)$ & $<0.001$ \\
\hline $\begin{array}{l}\text { Number of } \\
\text { times } \\
\text { dilated } \\
\text { (mean) }\end{array}$ & $\begin{array}{l}6.06 \\
( \pm 5.066)\end{array}$ & $3.10( \pm 2.644)$ & $<0.102$ \\
\hline $\begin{array}{l}\text { Mean } \\
\text { dilatation } \\
(\mathrm{mm})\end{array}$ & $\begin{array}{l}13.80( \pm 2.0 \\
78)\end{array}$ & $13.56( \pm 1.103)$ & $<0.740$ \\
\hline $\begin{array}{l}\text { Mean } \\
\text { symptomati }\end{array}$ & $\begin{array}{l}0.6919( \pm 0 . \\
3005)\end{array}$ & $0.3657( \pm 0.293$ & $<0.003$ \\
\hline $\begin{array}{l}\text { c } \\
\text { recurrences } \\
\text { per month }\end{array}$ & E & NDE & $\square$ \\
\hline
\end{tabular}

Acid-induced esophageal stricture generally has some symptoms including spitting, swallowing difficulty/pain on swallowing and chest pain. The typical symptom of esophageal stricture is difficulty in swallowing solid foods. Spontaneous vomiting is a sign of total obstruction. With these symptoms, clinicians use endoscopy to examine the stricture severity. If after exposure no symptoms are found, it can be estimated that $2-3 \%$ of damage is minimal (Kay, 2009; Hawkey, 2013). Pathogenesis of corrosive substances can directly damage the mucosa. Acid- or alkaline-induced damage can cause very different mucosal damage.

Alkaline-induced corrosive damage is more severe than acid due to necrosis liquefaction. Alkaline-induced mucosal damage over the esophageal stricture begins a few minutes to hours after exposure. Alkaline corrosive substances react with proteins and fats that subsequently will form lysis, resulting in the formation of necrosis liquefaction and penetration of very deep damage. Triggered by a considerable concentration and long contact time with the esophagus, the substances cause mucosal damage due to thrombosis in blood vessel walls. Acid-induced corrosive substances with a minimal concentration make the acid react with protein. This process will change the amino acids which subsequently causes necrosis coagulation due to mucosal damage, starting with eosinophilic necrosis formation (Mamede, 2001; Sandro, 2013)

General acute corrosive pathogenesis includes thrombosis occurrence in the veins and arteries, causing ischemia and inflammation. Mucosal peeling and bacterial infection occur in four to seven days after the incident. Granulation and ulcer are covered by fibrin, and perforation risk increases at this stage. On day four and five, fibroblasts appear on the affected tissue, causing an esophageal mold characterized by cell death and mucous secretion. Scar tissue starts to develop by the third week since collagen formation. Endoscopy and dilatation should be avoided five to fifteen days after this process. Scar tissue appears during the third week and develops for several weeks. This can lead to stricture and shortening of the gastrointestinal tract, causing increased pressure in the lower esophagus marked by increased gastroesophageal reflux (GER) which can lead to accelerated stricture. GER may indicate no dilated esophagus. A study found a low amplitude and no peristaltic contraction. Acidinduced esophageal stricture can lead to GER (Sandro, 2013).

Swallowing difficulty or pain on swallowing is commonly caused in cases with esophageal mucosal damage. This may increase exposure of chemo and thermal nociceptors with mucosa and submucosa. When this is active, the nerve conduction is delivered to unmyelinated $\mathrm{C}$-fibers or myelinated Apfibers causing pain to occur like a sharp object (Michael, 2016). Figure 3 shows the odynophagia algorithm.

The best examination for esophageal stricture or dysphagia complaints is barium swallow examination. This examination can provide important information, including stricture location, length and diameter and the esophagus wall condition. In addition, this examination can determine the esophageal transit time using solid barium with a chewing gum-like consistency. The barium swallow examination can also provide other information such as diverticulum and esophageal hernia. This examination has a $100 \%$ sensitivity to stricture with a diameter of less than $9 \mathrm{~mm}$ and $90 \%$ in strictures with diameters greater than $10 \mathrm{~mm}$ (Michael, 2016; Luedtke, 2003). Thoracic 
examination can be performed immediately to examine free air in the mediastinum since it signifies an esophageal perforation and free air in the diaphragm as a sign of gastric perforation (Skucas, 2000; Sandro, 2013).

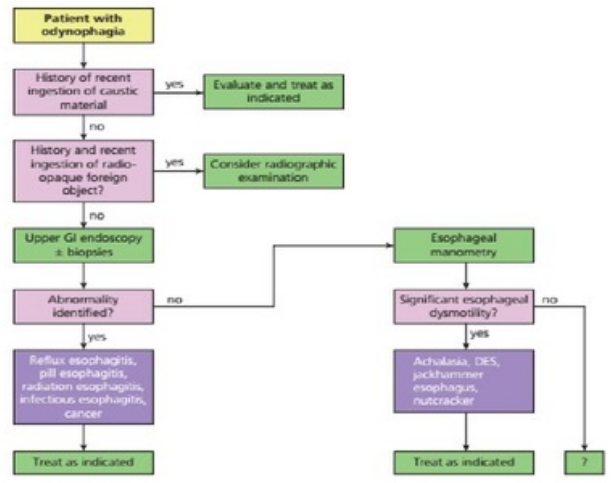

Figure 3: Odynophagia Algorithm (Michael, 2016).

In the case of a strong acid, endoscopy examination can be performed 12-48 hours after the incident, but it is better conducted 96 hours after the incident. Endoscopy and dilatation should not be performed 5-15 days after the incident due to a very high risk since the mucosa is still soft and in the healing process. Endoscopic examination should be discontinued when grade- 2 and 3 damage is found. Indications for endoscopy should be noted after clinical conditions, including symptoms, nose-throat, considering only $10-30 \%$ of general acid damage does not indicate mucosal damage to the upper gastrointestinal system. Radiologic contraindication of endoscopy is perforation or supraglottic or epiglottic edema, which is a sign of upper airway obstruction that serves as an indicator of intubation or tracheotomy. Endoscopic examination is an important stage to assess prognosis and management (Table 2). For grade 1 and 2 endoscopies, damage will not develop into esophageal stricture or gastric outlet obstruction. The increasing degree of esophageal damage will result in increased complications and death. Figure 4 describes the algorithm of esophageal stricture management caused by acid or alkali.

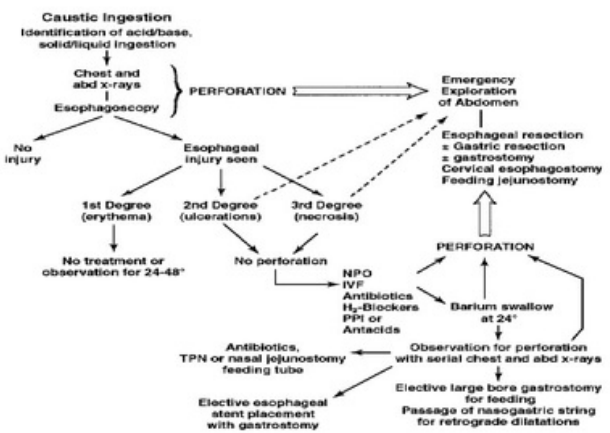

Figure 4: Caustic Esophageal Injury Therapy Algorithm (abd = abdomen; IVF = intravenous fluids; PPI = protonpump inhibitor, TPN $=$ total parenteral nutrition (Joseph, 2002)

Table 2: Classification of Caustic Injury from Endoscopic (Zargar, 1991).

\begin{tabular}{ll}
\hline Grade & Features \\
\hline Grade 0 & Normal \\
Grade 1 & Superficial mucosal edema and erythema \\
Grade 2 & $\begin{array}{l}\text { Mucosal and sub mucosal ulceration } \\
\text { Grade 2A }\end{array}$ \\
Superficial ulceration, erosions, exudates \\
Grade 2B & $\begin{array}{l}\text { Deep discrete or circumferentiall } \\
\text { ulceration }\end{array}$ \\
Grade 3 & $\begin{array}{l}\text { Transmural ulceration with necrosis } \\
\text { Focal necrosis }\end{array}$ \\
Grade 3A & Extensive necrosis \\
Grade 3B & Perforations \\
Grade 4 &
\end{tabular}

We present a case of a patient with a history of drinking car battery water while working. After the incident, the patient's throat was painful, it was difficult to swallow water and there was spitting. The esophagogram examination showed the contrast material only entered the middle esophagus and the patient choked. The endoscopy examination found esophageal stricture.

The therapeutic principle of esophageal stricture includes maintaining the esophageal mucosa in order for esophageal patency to remain favorable. If fibrotic tissue appears, it will preserve the esophagus diameter, minimize stricture and fibrosis tissue formation, and reduce mucosal tissue damage (Shawn, 2015). In acute conditions after exposure to strongly acidic substances, the initial therapy is usually conservative by hemodynamic stabilization and maintaining adequate airways. Intubation can be performed with laryngoscopy. Clinicians should avoid blind intubation as this results in a high risk of bleeding. Gastric cavity and emesis are contraindicated in post-exposure to strong acid 
cases, and milk or mineral water administration is very effective. Nasal hose installation can reduce aspiration and vomiting. Administration of a proton pump inhibitor and $\mathrm{H} 2$ blocker can reduce gastric acid-induced esophageal damage. The administration of steroids in esophageal stricture cases from 1956 to 2006 found no benefit, except in patients with airway disorders. Broad-spectrum antibiotics can be given with steroids (Cheng, 2008).

A complex esophageal stricture has a more difficult therapy since it requires more than three dilations to reduce symptoms. The relapse rate is very high if the esophageal stricture cannot be dilated adequately; therefore, the patient will not easily eat solid food, will recur within 2 to 4 weeks, and needs 7 to 10 dilatations to avoid relapse (Lew, 2002; Peter, 2008).

If clinical or radiological examination finds signs of perforated organs, laparotomy may be followed by esophagectomy, cervical esophagostomy, gastrostomy and jejunotomy feeding. Laparoscopy can be performed, but laparoscopy depends on the ability of the operator (Sandro, 2013).

Prevention of stricture formation includes steroids, antibiotics, nasogastric tube, mitomycin C and intraluminal stenting. Systemic steroid administration for stricture prevention is not useful, particularly on grade-III esophageal stricture Intralesional corticosteroid injections can decrease the proliferation of fibroblasts, collagen synthesis, glycosaminoglycan synthesis and suppress proinflammatory mediators. Intralesional steroid administration may be given periodically when scar tissue is established. The most widely used corticosteroid is triamcinolone acetate at a dose of 5$10 \mathrm{mg} / \mathrm{ml}$. Intralesional triamcinolone may be administered at a dose of $40 \mathrm{mg} / \mathrm{ml}$ mixed with $2 \%$ lidocaine at similar doses.

Intralesional triamcinolone administration is excellent in preventing stricture formation, but with optimal doses and good technique, will produce good results (Siersema, 2009). Triamcinolone administration can soften scars and keloids. A study concluded that intralesional triamcinolone can decrease the periodic dilatation index 1.45 times $(95 \%)$ with a confidence interval of $0.03-0.68$ and $p$ value of 0.0005 (Cuiling, 2015). Some studies have pointed out that antibiotic administration may reduce the occurrence of esophageal stricture. Patients with steroids should also be given antibiotics. Nasogastric tube installation can maintain esophageal diameter patency, but this can strongly contribute to the long stretching of the esophagus. Some studies have found that both nutrient administration using nasogastric tube installation and jejunotomy feeding have similar effects.

Mitomycin $\mathrm{C}$ is a chemotherapy drug that works on DNA crosslinking, which is useful to prevent stricture. Intraluminal stenting using silicon rubber or a polyflex stent can help reduce stricture, but the success rate is less than $50 \%$ with a $25 \%$ migration rate. A study reported that a 5-fluorouracil injection was effective in preventing stricture (Sandro, 2013).

The patient received endoscopy therapy, balloon dilatation and intralesional triamcinolone and methylprednisolone injections after the second endoscopy. The patient's complaints gradually improved; he could drink milk and $20 \mathrm{cc}$ of juice per hour and eat cereal, there was no vomiting, no spitting complaints, improved body weight and decreased weakness.

\section{CONCLUSIONS}

Esophageal stricture is esophageal luminal narrowing due to esophageal wall fibrosis. Esophageal stricture can be caused by a malignancy and non-malignancy, including strong acid. Manifestations of esophageal stricture include swallowing difficulty, particularly solid food, sore throat on swallowing, and history of drinking or ingestion of corrosive substances.

\section{REFERENCES}

CHENG, H. T., CHENG, C.L., LIN, C.H., TANG, J.H., CHU, Y.Y., LIU, N.J., CHEN, P.C. 2008. Caustic ingestion in adults: the role of endoscopic classifcation in predicting outcome. BMC Gastroenterol, 8, 31 .

CUILING, Z., XIAOYING, ZHOU., LIANZHEN, YU., JING, DING., AND RUIHUA, SHI. 2015. Efficacy of intralesional triamcinolone injections for benign refractory oesophageal strictures at Counties Manukau Health, New Zealand. The New Zealand Medical Journal, 128, 1416.

HARJADI, W. 2009. Anatomy Abdoment, Penerbit Buku Kedokteran EGC.

HAWKEY, C. J., BOSCH, J., RICHTER, J., CHAN, F. 2013. Textbook of Clinical Gastroenterology and Hepatology, Wiley-Blackwell

ILKIN, N. M., TUZUN, A., ERDIL, A., ATES, Y., BAGCI, S., YAMANEL, L., ET AL. 2006. Effectiveness of bougie dilation for the management of corrosive esophageal strictures. Acta Gastroenterol Belg, 69, 372-6.

JOSEPH, B., ZWISCHENBERGER, CLARE, SAVAGE., AND AKHIL, BIDANI. 2002. Surgical Aspect of Esophageal Disease Perforation and Caustic Injury. 
American Journal of Respiratory and Critical Care Medecine, 165, 1037-1040

KAY, M., WYLLIE, R. 2009. Caustic ingestions in children. Curr Opin Pediatr, 21, 651-654.

KHANNA, N. 2006. How do I dilate a denign esophageal stricture? . Can J Gastroenterol, 20, 153155.

LEW, R. J., ET AL. 2002. A review of endoscopic methods of esophageal dilation. J Clin Gastroenterol, $35,117-126$

LUEDTKE, P., LEVINE, M.S., RUBENSIN, S.E., ET AL. 2003. Radiologic Diagnosis of Benign Esophagela Strikture: A Pattern Approach Radiographics, 897-909.

MAMEDE, R. C., DE MELlo FILHO, F.V. 2001. Ingestion of caustic substances and its complications. Sao Paulo Med J 119, 10-15.

MICHAEL, C., J GREGORY, F., ANTHONY, N.K. FERGUS, S., TIMOTHY, C.W. 2016. Yamada'S Textbook of Gastroenterology, Willey-Blackwell

OSMAN, M., RUSSELL, J., SHUKLA, D, MOGHADAMFALAHI, M., GRANGER, D.N. 2008. Responses of the murine esophageal microcirculation to acute exposure to alkali, acid, or hypochlorite. $J$ Pediatr Surg, 43, 1672-1678.

PETER, D. S. 2008. Treatment Option for Esophageal Stricture. nature clinical practice. GASTROENTEROLOGY \& HEPATOLOGY, 142-152.

SAJIDA, Q., SHAHRIYAR, GHAZANFAR., AFTAB, LEGHARI., FAHAD, TARIQ., SAAD, KHALID.NIAZ., MOHAMMAD,

SAEED.QURAISHY. 2010. Benign esophageal strictures: Behaviour, pattern and response to dilatation. JPak Med Assoc, 60, 656-660.

SANDRO, C., CARMELO, SCARPIGNATO. 2013. Caustic injury of the upper gastrointestinal tract: A comprehensive review. World J Gastroenterol 39183930

SHAWN, S., GROTH, D., ODELL, JAMES, D. 2015. Esophageal Strictures Refraktory to Endoscopy Dilatation. Gastrointestinal Surgery, 13-21

SIERSEMA, P. D., DE WIJKERSLOOTH, L.R. 2009 Dilation of refractory benign esophageal strictures Gastrointest Endosc 70, 1000-1012

SIMADIBRATA, M. 2009. Buku Ajar Ilmu Penyakit Dalam, Jakarta Interma Publishing.

SKUCAS, J. 2000. Contrast media, Philadelphia, WB Saunders.

ZARGAR, S. A., KOCHHAR, R., MEHTA, S., MEHTA, S.K. 1991. The role of fberoptic endoscopy in the management of corrosive ingestion and modified endoscopic classification of bums. Gastrointest Endosc, 37, 165-169. 
Management of a Patient with Esophageal Stricture after Drinking Strongly Acidic Water

ORIGINALITY REPORT

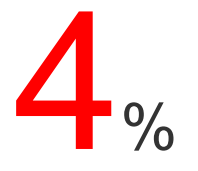

SIMILARITY INDEX
$3 \%$

INTERNET SOURCES
$3 \%$

PUBLICATIONS
$0 \%$

STUDENT PAPERS

\section{PRIMARY SOURCES}

1 www.omicsonline.org

2 www.scitepress.org

3 Usman Hadi. "Optimizing antibiotic usage in adults admitted with fever by a multifaceted intervention in an Indonesian governmental hospital : Optimizing antibiotic usage", Tropical Medicine \& International Health, 03/27/2008 Publication

Purnami Nyilo, Manyakori Serafika Permoni

Putri. "The Association of Reactive Oxygen

Species Levels on Noise Induced Hearing Loss

of High Risk Workers in Dr. Soetomo General

Hospital Surabaya, Indonesia", Indian Journal of

Otolaryngology and Head \& Neck Surgery, 2018

Publication 
Mark Anthony A De Lusong, Aeden Bernice G Timbol, Danny Joseph S Tuazon. "Management of esophageal caustic injury", World Journal of Gastrointestinal Pharmacology and Therapeutics, 2017

Publication

Matthew B. Singer, Andrew Tang. "Esophagus, Stomach, and Duodenum", Wiley, 2018 


\section{Management of a Patient with Esophageal Stricture after Drinking Strongly Acidic Water}

GRADEMARK REPORT

FINAL GRADE

10

PAGE 1

PAGE 2

PAGE 3

PAGE 4

PAGE 5

PAGE 6

PAGE 7
GENERAL COMMENTS

Instructor 